\title{
DIGNITY
}

Dignity: A Journal of Analysis of Exploitation and Violence

\section{Book Review: Prostitution Narratives: Stories of Survival in the Sex Trade, Edited by Caroline Norma and Melinda Tankard Reist}

Abigail Bray

Social science research consultant, Australia and France

Follow this and additional works at: https://digitalcommons.uri.edu/dignity

Part of the Community-Based Learning Commons, Criminology Commons, Domestic and Intimate Partner Violence Commons, Gender and Sexuality Commons, Health Policy Commons, Inequality and Stratification Commons, Nonfiction Commons, Politics and Social Change Commons, Public Policy Commons, Social Control, Law, Crime, and Deviance Commons, Social Policy Commons, Social Psychology Commons, Social Work Commons, and the Women's Studies Commons

\section{Recommended Citation}

Bray, Abigail (2017) "Book Review: Prostitution Narratives: Stories of Survival in the Sex Trade, Edited by Caroline Norma and Melinda Tankard Reist," Dignity: A Journal of Analysis of Exploitation and Violence: Vol. 2: Iss. 2, Article 7. https://doi.org/10.23860/dignity.2017.02.02.07

This Book Review is brought to you for free and open access by DigitalCommons@URI. It has been accepted for inclusion in Dignity: A Journal of Analysis of Exploitation and Violence by an authorized editor of DigitalCommons@URI. For more information, please contact digitalcommons-group@uri.edu. 
Book Review: Prostitution Narratives: Stories of Survival in the Sex Trade, Edited by Caroline Norma and Melinda Tankard Reist

\author{
Keywords \\ prostitution, sex trade, survivors, abolition, sexual violence, exploitation \\ Creative Commons License \\ (c) $(1) \Theta \Theta$
}

This work is licensed under a Creative Commons Attribution-Noncommercial-No Derivative Works 4.0 License. 
DIGNITY

Volume 2, Issue 2, Article 7, 2017
A JOURNAL ON

SEXUAL EXPLOITATION

AND VIOLENCE

\author{
BOOK REVIEW: PROSTITUTION NARRATIVES: \\ STORIES OF SURVIVAL IN THE SEX TRADE \\ EDITED BY CAROLINE NORMA AND MELINDA TANKARD REIST \\ SPINIFEX PRESS, MELBOURNE, 2016, 200 PAGES \\ Abigail Bray \\ Social science research consultant, Australia and France
}

\title{
KEYWORDS
}

prostitution, sex trade, survivors, abolition, sexual violence, exploitation

$\mathrm{P}$ PROSTITUTION HAPPENS IN COMMUNITIES. Let me describe one briefly. Fremantle, Western Australia, is a colonial seaside town with a reputation for being cosmopolitan, funky and progressive, boasting numerous hipster boutiques and cafes, a vibrant art scene. Manna, the town's coolest health food shop and cafe, sells organic bio-dynamic products, vegan cook books; it's windows carry colorful invitations to yoga classes, alternative therapy workshops, and fullmoon drumming circles on the local beaches. Educated, middle-class health conscious people with an ethical commitment to the well-being of the earth and our fellow animals tend to gravitate there, happily gossiping at the tables outside on their way to and from the beach.

Over the road from Manna, there is a building with bricked up windows painted in factory gray. The atmosphere around this building is strangely still and silent - one senses that something inside is being constrained and soundproofed. A pavement sign beside the side entrance reads "Ada Rose. Gentleman's club. Open." Their website reads: "Ada Rose is the longest established brothel and escort agency in Perth, operating for over 30 years from its premises in South Fremantle. This historic South Tce building has been refurbished and restored to its former glory, offering old fashioned customer service for gentlemen." Among the oldfashioned customer services men can buy are "kinky adventures." Prices range from AU $\$ 120$ to AU $\$ 600$. This gray, silent building also sells "affection."

There is a conspicuous local silence about Ada Rose. Conversations are cut short with brief, salacious jokes, and further attempts at discussion are routinely blocked with mindless neo-liberal mantras about "choice" and "selfempowerment." Suggesting that anything harmful to women might be happening within the gray building is taboo, part of an unspoken community rule among the local progressives who have decided that those who make even the slightest critique of the sex industry are not-very-Fremantle. And one senses, beneath this, a community pride in the brothel, as though it gives the town an edgy glamor, a risqué vibe. Oh wow, a brothel, how cool! Indeed, when Ada Rose was revamped, 45 locals, including members of the Fremantle Council, celebrated together at breakfast hosted by the brothel (Malborough, 2017). 
In Prostitution Narratives: Stories of Survival in the Sex Trade, edited by Caroline Norma and Melinda Tankard Reist, survivors break the silence about the kind of "gentlemen" brothels such as Ada Rose cater to. Twenty survivors from seven wealthy countries bear witness to the sexual, emotional, economic, psychological and physical abuse to which (mostly older) men subject (mostly younger) women. Cross-disciplinary research spanning decades has repeatedly found evidence that men who buy women for what is called "sex" inflict harm on those women. This collection is the first-time multiple survivors have spoken-out about direct personal experiences of that harm. Prostitution Narratives is a courageous and rational reply to sexual exploitation industry money and its allies, the coin-operated megaphones of self-serving libertarians who shout "Moral panic!" "Moral panic!" whenever survivors dare to speak out about the criminal destruction of women within the so-called "sex industry."

As Caitlin Roper puts it: "It is only when men are held accountable for their abuse of women in the sex trade that we will see meaningful progress" (p.212). This book calls those men to account. Who are these men who are defended so often, their crimes unreported, whose right to buy human bodies is seen as natural, normal, even therapeutic? As one survivor states, from experience, "sex buyers are some of the sickest of the sick" (p.137). Some survivors also speak out about a lot of men occupying positions of significant power, nameless powerful, shadowy abusers, and organized groups of men preying on vulnerable girls.

Progressive men often argue that prostitution is a job like any other.

"So, here I was, a small sixteen year old girl locked in a room where men would come to threaten, beat and rape me or take me to other men who would pay to rape me. My life had ended that first day, my mind had completely shut down - Suzzan Blac (p.192)

Progressive men often say that prostitution is harmless.

I am hurting from a past no one should know

a past made of gang-rapes,

of being alone with men who see nothing

but an object to destroy,

of wanting to die but fighting to stay alive. - Rebecca Mott (p.187)

Progressive men often say that women feel empowered by prostitution.

I was gagged, choked, gang raped, pushed, pulled by the legs, shoved, yelled at, threatened, lied to, anally raped, filmed and photographed naked with and without my consent. - Genevieve Gilbert (p.175)

Progressive men often say that prostitution is a choice.

I began volunteering at a drop-in centre for prostituted women. I was shocked at what I saw. Most of the women in the room were of Native ancestry, and most of them looked like death camp survivors. - Jacqueline Lynne (p.167) 
These are stories from the patriarchal abyss, and it requires a certain maturity of spirit to "hear" what they have witnessed, what they are naming and expelling. Writing that creates paradigm shifts in social justice is often heart-breaking. To read this book is to let one's heart be broken open to the reality of prostitution.

Prostitution Narratives is a vital contribution to the international abolitionist movement which has long argued that prostitution is a form of "female sexual slavery" (Barry, 1979). In their powerful introductory deconstruction of dominant sex industry myths about prostitution, editors Caroline Norma and Melinda Tankard Reist, both leading international experts, quote the abolitionist Melissa Farley who points out that "the information [on the harms of prostitution, pornography, and trafficking] has to be culturally, psychologically, and legally denied because to know it would interfere with the business of exploitation" (p.2). This central point draws attention to the economic function of the hegemonic cultural denial of women's suffering in the sex industry. As Norma and Reist write: "Powerful political, economic and cultural forces operate to make unspeakable their violation, suffering, torment, and death" (p.5). These opportunistic forces seek to conserve men's right to exploit women because there is a vast amount of money to be made in subjugating human beings. Yet, ironically, defending the sex industry is often not seen as conservative, but as progressive and enlightened, while those who call attention to the systemic abuse of women in the industry are routinely dismissed as conservatives or crypto-fundamentalist Christians.

Within prostitution enabling communities such as Fremantle, those who challenge the authority of the political, economic and cultural forces which support the continuation of female sexual slavery are often shunned and denied the right to speak. Survivors who dare to break the silence about the truth of prostitution, as many of the women here testify, are frequently persecuted. Yet the existence of this book and the growing international abolitionist movement indicates that decades of struggle against the organized, commercial sexual abuse of females is successfully overcoming the silence and lies (and quite frankly, the astonishing stupidity) of the industry and their allies. "As testimony, Prostitution Narratives aims to contribute to campaigns directed at stopping the sex industry as an enterprise that inflicts the trauma described by our contributors," write the editors (p.11). I am certain that this book has already mobilized many and will continue to do so. One thing that struck me in reading this book is the determined solidarity at work in the whole project. This solidarity, this unshakable integrity, dignity of purpose, and will to justice and healing will ultimately overcome the lies of the sexual abuse industry and their apologists.

\section{AUTHOR BIOGRAPHY}

Dr. Abigail Bray is an interdisciplinary social scientist with areas of concentration in critical psychology, race, and gender. Bray is the author or editor of numerous articles and books, including Misogyny Re-loaded (2013, Spinfex Press) and Big Porn, Inc.: Exposing the Harms of the Global Porn Industry (2012, Spinifex Press), and has held several research positions in Australia.

\section{RECOMMENDED CITATION}

Bray, Abigail. (2017). Book review: Prostitution narratives: Stories of survival in the sex trade, Edited by Caroline Norma and Melinda Tankard Reist. Dignity: A Journal of 
Sexual Exploitation and Violence. Vol. 2, Issue 2, Article 7. Available at http://digitalcommons.uri.edu/dignity/vol2/iss2/7.

DOI:10.23860/dignity.2017.02.02.07

\section{REFERENCES}

Ada Rose Gentleman's Club http://www.adarose.com.au

Barry, Kathleen. (1979) Female sexual slavery. New York: New York University Press.

Malborough, Patrick (2017) An evening at the last brothel in Fremantle. Vice. March 22

https://www.vice.com/en_au/article/a-evening-at-the-last-brothel-in-fremantle 